\title{
Formulating a Strategic Plan for BIM Diffusion within the AEC Italian Industry: The Application of Diffusion of Innovation Theory
}

\author{
Behzad Karampour', Sherif Mohamed ${ }^{2},{ }^{*}$ Hassan Karampour² and \\ Sonia Lupica Spagnolo'
}

First submission: 27 April 2020; Accepted: 23 August 2020; Published: 30 July 2021

To cite this article: Behzad Karampour, Sherif Mohamed, Hassan Karampour and Sonia Lupica Spagnolo (2021). Formulating a strategic plan for BIM diffusion within the AEC Italian industry: The application of diffusion of innovation theory. Journal of Construction in Developing Countries, 26(1): 161-184. https://doi.org/10.21315/jcdc2021.26.1.8.

To link to this article: https://doi.org/10.21315/jcdc2021.26.1.8

\begin{abstract}
The importance of digital skills diffusion in fostering the architecture, engineering and construction (AEC) industry has been highlighted for more than a decade. The extent to which this objective can be achieved depends on several factors. An augmented building information modelling (BIM) adoption stems from, but is not restricted to, government policies and initiatives. This study aims to assess the diffusion of digital skills, specifically through BIM adoption and to establish feasible strategies for such adoption within the Italian AEC industry, taking into account institutional, organisational and project-related factors. This purpose is achieved through an initial investigation of the most significant hurdles in BIM uptake and various BIM-promoting policies adopted at an international level. Moreover, a rigorous review of recent developments in the diffusion of innovation theory is presented. Based on findings and combining the experiences of various authors in BIM-related research an exploratory online survey was conducted, resulting in identification of the clients' lack of knowledge as the most critical challenge to BIM adoption in the Italian AEC industry. Following this finding, the study suggests five strategies to leverage BIM benefits to their full extent, to increase the perception of BIM benefits and to bridge the current gap between the industry and academia.
\end{abstract}

Keywords: Digital skills diffusion, Diffusion of innovation theory, Building information modelling, BIM adoption, BIM barriers

\section{INTRODUCTION}

The construction industry, as a whole, is slow at adopting new technologies (Cao et al., 2017: 1; Shakil and Hoque, 2018: 111). Thus, researchers emphasise the need for a greater probe into the spread of innovation within the architecture, engineering and construction (AEC) industry (Gledson and Greenwood, 2017; Ya'acob, Rahim and Zainon, 2018). Despite the industry's awareness of the importance of the trend towards digitisation, it still suffers from a "digital divide" (Ayinla and Adamu, 2018: 2). Therefore, those companies that fail to develop and implement their own digitisation strategies will lose ground in terms of productivity improvement and business advancement (Roland Berger, 2015: 4). Challenges in innovation diffusion in the construction industry as a complex social system are derived not only from the distinct organisational and structural characteristics of construction firms (Shibeika and Harty, 2015: 456) but also from government supports (Rogers, Chong and Preece, 2015: 431).

\footnotetext{
'Department of Architecture, Construction Engineering and Built Environment (ABC), Politecnico di Milano, Milan, ITALY

${ }^{2}$ School of Engineering and Built Environment, Griffith University, Gold Coast, QLD, AUSTRALIA

*Corresponding author: h.karampour@griffith.edu.au
} 
The Italian construction industry accounts for $18.7 \%$ of the country's gross domestic product and is deemed vital to the country's economy (European Construction Sector Observatory, 2018: 2). However several factors are placing the viability and the profitability of the industry at risk, namely, inefficient public spending, corruption within the administrative procedures, lack of transparency in the domestic market. The latter two are directly impeding entry to the single European Union (EU) market and the leveraging of its financial advantages (European Construction Sector Observatory, 2018: 26). By introducing the recent decree mandating building information modelling (BIM) use for all projects by 2025, the Italian government took a major step towards digitising the industry and aligning itself with the initiatives of its major European counterparts to alleviate the underlying problems of the industry and help to grease the wheels of the economy.

Further, according to the "BIM Decree" issued in December 2017, the mandate targets initially complex public works exceeding 100 million euros and it will be extended to all ordinary projects only after 2025. While this approach may prove to be effective for major public companies, it disregards the important role of private entities within the industry. According to Norsa (2019: 1), the private sector in Italy accounts for about three-quarters of the country's construction market. Therefore, this study has focused its attention on private companies in regard to BIM diffusion.

Even though many authors so far have discussed separately the significant hurdles involved in BIM adoption deriving from both institutional contexts and organisational structures (Hosseini et al., 2016: 75; Gledson and Greenwood, 2017: 964; Shibeika and Harty, 2015: 459; Kassem, Brogden and Dawood, 2012: 6), few have sought to provide integrated solutions to address different types of barries. This study, from its inception, has reiterated the importance of integrating institutional and organisational barriers to BIM uptake within the Italian industry.

The study initially scrutinises and categorises the most significant barriers to BIM adoption according to different authors. Then, the Italian government's contribution to the promotion of BIM use is compared with BIM adoption in other successful countries. Subsequently, to gain a better understanding of potential areas for improvement in terms of BIM adoption in Italy, the fundamental principles of the diffusion of innovation (DOI) theory (Rogers, 2003: 11) in conjunction with its latest developments and extensions (Shibeika and Harty, 2015; Gledson and Greenwood, 2017) are investigated and incorporated in an online survey that forms the baseline for establishing BIM-promoting strategies suitable for the Italian industry.

\section{RESEARCH BACKGROUND}

\section{Barriers to BIM Adoption}

Kassem, Brogden and Dawood (2012: 1) stress that the identification of barriers to BIM adoption can serve as an overture to BIM adoption. Essentially, it is clear that there is a discrepancy in the adoption of BIMs between small or medium-sized enterprises (SMEs) and large-scale firms (Hosseini et al., 2016: 72). Park and Kim (2014: 473) argue that the problems for BIM adoption need to be addressed on three grounds: (1) business and legal barriers, (2) technical barriers and (3) human or organisational barriers, and Gu and London (2010: 989) classify the issues in BIM 
adoption under two areas: technical tool functional and non-technical strategic issues. Ahuja et al. (2018: 4) categorise the significant drivers of BIM adoption into technical, organisational and environmental factors and discuss the different significant hurdles in the Indian construction sector in relation to each category; they consider the complexity of the BIM implementation process, perceived cost of BIM, the lack of BIM expertise (technical knowledge), the paucity of government incentives and the absence of the standardisation of implementation processes, among other barriers.

Thus, to obtain a better perception of the barriers to BIM adoption, we need to differentiate between the challenges arising from the organisational and structural characteristics of companies, government attributes of the country in which the firm is based as well as other human factors. In Table 1, the different hurdles for BIM adoption according to different references are further discussed and classified into three categories: institutional barriers, organisational/humancentred barriers and technological/project-based barriers (some barriers belong to different categories).

Table 1. The Most Significant Barriers to BIM Adoption According to Different Authors

\begin{tabular}{|c|c|c|}
\hline Barrier & Source & Type of Barrier \\
\hline $\begin{array}{l}\text { Lack of support } \\
\text { and incentives from } \\
\text { governments }\end{array}$ & $\begin{array}{l}\text { Matarneh and Hamed (2017), Ayinla } \\
\text { and Adamu (2018), Hosseini et al. (2016), } \\
\text { Zahrizan et al. (2013), Nanajkar and Gao } \\
\text { (2014), Ahuja et al. (2018) and Sherif et al. } \\
\text { (2018) }\end{array}$ & Institutional \\
\hline $\begin{array}{l}\text { Absence of standards } \\
\text { and guidelines }\end{array}$ & $\begin{array}{l}\text { Hosseini et al. (2016), NBS (2018), Matarneh } \\
\text { and Hamed (2017) and Chan (2014) }\end{array}$ & Institutional \\
\hline $\begin{array}{l}\text { Lack of knowledge } \\
\text { and awareness }\end{array}$ & $\begin{array}{l}\text { Gu and London (2010), Kassem, Brogden } \\
\text { and Dawood (2012), Matarneh and } \\
\text { Hamed (2017), Hosseini et al. (2016), } \\
\text { Zahrizan et al. (2013) and Khosrowshahi } \\
\text { and Arayici (2012) }\end{array}$ & $\begin{array}{l}\text { Institutional/ } \\
\text { organisational, } \\
\text { human-centred }\end{array}$ \\
\hline No client demand & $\begin{array}{l}\text { NBS (2018), Rogers, Chong and Preece } \\
\text { (2015), Chan (2014), Matarneh and } \\
\text { Hamed (2017), Ayinla and Adamu (2018), } \\
\text { Khosrowshahi and Arayici (2012), Hosseini } \\
\text { et al. (2016) and Ahuja et al. (2018) }\end{array}$ & $\begin{array}{l}\text { Institutional/ } \\
\text { project-related } \\
\text { and technological }\end{array}$ \\
\hline $\begin{array}{l}\text { Lack of in-house } \\
\text { expertise }\end{array}$ & $\begin{array}{l}\text { NBS (2018), Rogers, Chong and Preece } \\
\text { (2015), Chan (2014), Ayinla and Adamu } \\
\text { (2018), Matarneh and Hamed (2017), } \\
\text { Hosseini et al. (2016) and Ahuja et al. } \\
\text { (2018) }\end{array}$ & $\begin{array}{l}\text { Organisational, } \\
\text { human-centred }\end{array}$ \\
\hline $\begin{array}{l}\text { Resistance to change, } \\
\text { culture-centred }\end{array}$ & $\begin{array}{l}\text { Rogers, Chong and Preece (2015), } \\
\text { Matarneh and Hamed (2017), Ayinla } \\
\text { and Adamu (2018), Hosseini et al. (2016) } \\
\text { and Khosrowshahi and Arayici (2012) }\end{array}$ & $\begin{array}{l}\text { Organisational, } \\
\text { human-centred }\end{array}$ \\
\hline
\end{tabular}


Behzad Karampour et al.

Table 1. Continued

\begin{tabular}{|c|c|c|}
\hline Barrier & Source & Type of Barrier \\
\hline $\begin{array}{l}\text { Technology and } \\
\text { interoperability }\end{array}$ & $\begin{array}{l}\text { Rogers, Chong and Preece (2015), } \\
\text { Matarneh and Hamed (2017), Ayinla and } \\
\text { Adamu (2018), Hosseini et al. (2016), Ahuja } \\
\text { et al. (2018) and Sherif et al. (2018) }\end{array}$ & $\begin{array}{l}\text { Project-related } \\
\text { and technological }\end{array}$ \\
\hline $\begin{array}{l}\text { Lack of training/ } \\
\text { education }\end{array}$ & $\begin{array}{l}\text { NBS (2018), Rogers, Chong and Preece } \\
\text { (2015), Chan (2014), Burgess, Jones and } \\
\text { Muir (2018), Matarneh and Hamed (2017), } \\
\text { Hosseini et al. (2016) and Ahuja } \\
\text { et al. (2018) }\end{array}$ & $\begin{array}{l}\text { Organisational, } \\
\text { human-centred }\end{array}$ \\
\hline $\begin{array}{l}\text { Costs (software, } \\
\text { training, time, suitable } \\
\text { technology), risks of } \\
\text { adoption }\end{array}$ & $\begin{array}{l}\text { NBS (2018), Rogers, Chong and Preece } \\
\text { (2015), Matarneh and Hamed (2017), } \\
\text { Ayinla and Adamu (2018), Hosseini et al. } \\
\text { (2016), Khosrowshahi and Arayici (2012), } \\
\text { Ahuja et al. (2018) and Sherif et al. (2018) }\end{array}$ & $\begin{array}{l}\text { Organisational, } \\
\text { human-centred/ } \\
\text { Project-related } \\
\text { and technological }\end{array}$ \\
\hline
\end{tabular}

\section{The Roles of Governments and Global Strategies}

This paper does not intend to elaborate on the different policies implemented in various countries, rather it examines their relative approaches taken by different countries towards BIM adoption and the results of these approaches.

\section{United States (US)}

The US General Services Administration (GSA) initially formulated the national 3D-4D-BIM Programme in 2003. This programme mandated BIM adoption for all public service building projects in 2007. The GSA also partnered with BIM vendors, federal agencies, professional associations, open-standard organisations and academic/research institutions to develop a community of BIM leaders (Cheng and Lu, 2015: 445). Consequently, levels of BIM adoption in North America rose from 28\% to 71\% between 2007 and 2012 (McGraw-Hill Construction, 2012: 4). Moreover, in 2014, according to McGraw-Hill Construction (2015: 8-11), US was a leader in terms of years of BIM experience (with $28 \%$ of BIM users having between 6 and 10 years of BIM experience), BIM expertise (with $35 \%$ operating at advanced BIM levels) and BIM implementation level (with $79 \%$ exhibiting high/very high BIM implementation levels).

\section{United Kingdom (UK)}

UK devised 12 action plans to utilise its position as the leader in BIM exploitation and to create growth for the UK market (HM Government, 2013: 65). As a consequence of a five-year initial programme in 2016, the UK government mandated Level 2 BIM implementation in public-sector projects. Moreover, according to Sielker and Allmendinger (2018: 15), the UK government established the UK BIM Task group in order to assist clients and supply chain through intensive collaboration between governmental departments, industry, academia and estate clients, which is why the 
UK government stimulated BIM use by client role as well. BIM usage and awareness increased substantially from $48 \%$ in 2015 to $74 \%$ in 2018, while BIM knowledge and skills enjoyed a $13 \%$ boost between 2015 and 2018 (it currently sits at 58\%) (NBS, 2018: 19).

\section{Scandinavian countries}

In Denmark, the use of Industry Foundation Classes (IFC) certification initially set the proper background for the use of BIM. With a leading role in developing BIM classification standards, Denmark promoted BIM implementation in Europe (Jensen and Jóhannesson, 2013). The Danish government initiated a digital construction project in 2007, which mandated the use of BIM in all public construction projects (Wong, Wong and Nadeem, 2010: 290). As of 2016, Denmark's BIM usage was at 78\%, which was higher than that of the UK (48\%) (NBS, 2016: 7).

In Norway, after the government had expressed its commitment to BIM adoption in 2010, many public sectors launched programmes in its support. Statsbygg, a public administration company and a Norwegian key adviser mandated the use of BIM and, by 2010, all its projects used BIM models based on IFC and IFD (Cheng and LU, 2015: 454).

\section{Australia}

In 2016, a report by the Australian government's standing committee on infrastructure, transport and cities exhorted the creation of a smart infrastructure task force (just like the UK task group). The Australian Government has so far opted not to mandate BIM and has settled, instead, for a gradual and voluntary approach. Nevertheless, from 2009 onwards many initiatives have been developed to inform project stakeholders about potential productivity gains and the securing of competitive advantages (Smith, 2014: 486). The "National BIM Guide" by the National Specifications (NATSPEC), "National Guide for Digital Modelling" by the Australian Cooperative Research Center for Construction Innovation (CRC-CI) and Australian and New Zealand Revit Standards (ANZRS), are among the most important BIM guides developed in Australia (Cheng and Lu, 2015: 465). In 2015, the McGraw-Hill Construction (2015: 54) displayed Australia's exceptional leadership in external collaborative processes (50\%), while arguing that $50 \%$ of contractors in Australia and New Zealand had been using BIM for only 3 to 5 years by that stage and were therefore newer BIM users with lower engagement levels.

\section{Italy}

In Italy under the law in 2013, IBIMI, an alliance that incentivise the diffusion of digital innovation in the construction industry, was established; it is currently operating under buildingSMART Italy, which was founded previously in 2004. Further, in 2014, the government supported and funded a three-year project, INNovance, aimed at developing a standardised national BIM library and involving some of Italy's primary construction companies, three universities and associations for manufacturers of building components (Pasini et al., 2017: 2). The first government action to support BIM implementation was triggered as a result of the "BIM decree" in December 
2017, in which the contracting authorities mandated the use of "digital tools and methods". The decree requires BIM implementation in various phases in anticipation of a fully digitised BIM-using industry for projects amounting less than EUR 1 million by 2025 , as follows:

1. Until 2019, BIM use was mandated for complex works exceeding EUR100 million.

2. From 2019 to 2021 , the attention of the mandate will be on the project's complexity rather than its cost.

3. From 2022, the mandate will require all ordinary public works, as well as complex works, to use BIM.

\section{Comparison between the roles of governments and global strategies}

Government strategies vary considerably and the degree of success of each strategy should be viewed alongside the characteristics of the country. This study has opted to investigate the aforementioned countries for each of which has achieved significant breakthroughs in BIM adoption by means of its own unique approaches; in the US, the contribution to BIM on different levels; in the UK, the linking of industry, academia and clients through the establishment of a task force; in Scandanavian countries, the contribution of major public enterprises and the requirement for IFC-compliant BIM modelling; in Singapore, the mandating of e-submissions and IFC-compliant BIM modelling; and in Australia, the raising of awareness of the benefits of BIM and the development of various national BIM guidelines (as shown in Table 2).

Table 2. Comparison between Various Government Strategies

\begin{tabular}{|c|c|c|c|}
\hline Country & Drivers and Mandates & Focus & $\begin{array}{l}\text { Distinguishing Feature and } \\
\text { Main Enablers }\end{array}$ \\
\hline US & $\begin{array}{l}\text { Requiring BIM for } \\
\text { government projects } \\
\text { from } 2007\end{array}$ & $\begin{array}{l}\text { Requiring BIM use } \\
\text { for public service } \\
\text { buildings through } \\
\text { public bodies } \\
\text { from } 2007\end{array}$ & $\begin{array}{l}\text { The contribution to BIM } \\
\text { up-take on different levels: } \\
\text { university, national, state, } \\
\text { public bodies }\end{array}$ \\
\hline UK & $\begin{array}{l}\text { Mandating level } 2 \text { BIM } \\
\text { in } 2016\end{array}$ & $\begin{array}{l}\text { Public service } \\
\text { buildings and } \\
\text { infrastructure }\end{array}$ & $\begin{array}{l}\text { The government role is } \\
\text { highlighted also as a client; } \\
\text { establishing a BIM task group } \\
\text { to link industry, academia, } \\
\text { clients; delivering annual } \\
\text { reports on BIM }\end{array}$ \\
\hline Denmark & $\begin{array}{l}\text { Digital construction } \\
\text { project required BIM } \\
\text { Use in public projects in } \\
2007 \text {; mandating BIM } \\
\text { from } 2013 \text { for projects } \\
\text { exceeding DKK5 }\end{array}$ & $\begin{array}{l}\text { Public } \\
\text { infrastructure }\end{array}$ & $\begin{array}{l}\text { Implementing a digital } \\
\text { construction project in } 2007 \\
\text { is deemed to be the turning } \\
\text { point in BIM adoption; many } \\
\text { state clients followed the } \\
\text { initiative }\end{array}$ \\
\hline
\end{tabular}


Table 2. Continued

\begin{tabular}{|c|c|c|c|}
\hline Country & Drivers and Mandates & Focus & $\begin{array}{l}\text { Distinguishing Feature and } \\
\text { Main Enablers }\end{array}$ \\
\hline Finland & $\begin{array}{l}\text { The Senate, a major } \\
\text { public enterprise, } \\
\text { required IFC-compliant } \\
\text { BIM modelling in } 2007\end{array}$ & $\begin{array}{l}\text { Public } \\
\text { infrastructure }\end{array}$ & $\begin{array}{l}\text { First country to adopt BIM } \\
\text { standards and to require } \\
\text { IFC-compliant BIM }\end{array}$ \\
\hline Norway & $\begin{array}{l}\text { In } 2010 \text {, Statsbygg, } \\
\text { a public enterprise } \\
\text { mandated IFC- } \\
\text { IFD compliant BIM } \\
\text { modelling }\end{array}$ & $\begin{array}{l}\text { Public } \\
\text { infrastructure }\end{array}$ & $\begin{array}{l}\text { Statsbygg as a key } \\
\text { government advisor, has } \\
\text { contributed in developing } \\
\text { standards, manuals, funding } \\
\text { research projects and } \\
\text { mandating IFC-IFD compliant } \\
\text { modelling }\end{array}$ \\
\hline Singapore & $\begin{array}{l}\text { Level } 3 \text { BIM mandate } \\
\text { from } 2015 \text { for buildings } \\
\text { above } 5,000 \text { sq m; } \\
\text { mandating e-submissions } \\
\text { for construction projects }\end{array}$ & $\begin{array}{l}\text { All types of } \\
\text { projects above } \\
5,000 \mathrm{sq} \mathrm{m}\end{array}$ & $\begin{array}{l}\text { The CORENET programme } \\
\text { enabled an IFC compliant } \\
\text { BIM modelling industry; the } \\
\text { first e-submission platform } \\
\text { in construction industry }\end{array}$ \\
\hline Australia & $\begin{array}{l}\text { No government } \\
\text { mandate }\end{array}$ & No mandate & $\begin{array}{l}\text { Government is targeting } \\
\text { gradual BIM adoption } \\
\text { through higher perception } \\
\text { of its productivity; National } \\
\text { BIM guidelines and initiatives; } \\
\text { strong presence in addressing } \\
\text { software related issues }\end{array}$ \\
\hline Italy & BIM mandate from 2019 & $\begin{array}{l}\text { For complex } \\
\text { works exceeding } \\
\text { EUR100 million }\end{array}$ & $\begin{array}{l}\text { Developing a national BIM } \\
\text { library }\end{array}$ \\
\hline
\end{tabular}

\section{DOI Theory}

According to Rogers's DOI theory, "innovation is an idea, practice, or project that is perceived as new by an individual or other unit of adoption" (Rogers, 2003: 12). Such a theory scrutinises how an idea spreads within specific homogeneous social systems. Early studies focused on personal innovation adoption behaviours and established five stages during which the DOI takes place: (1) knowledge, (2) persuasion, (3) decision, (4) implementation and (5) confirmation (Rogers, 2003: 165). Consequently, studies have extended the theory to discern differences between the process of the adoption of innovation in organisations, in assorted social systems and in individuals (Shibeika and Harty, 2015; Gledson and Greenwood 2017). Basing their study on Rogers's DOI theory, Gledson and Greenwood (2017: 964) discuss how the increase in the rate of adoption in the case of 4-dimensional (4D) BIM is mostly explained by its relative advantages in communicating the construction plan, its compatibility with existing planning practices and its capacity to be tested in a safe environment prior to use in a live construction project, among other perceived attributes. They argue that the most frequent decision type for adopting 4D BIM is the authority-type, made by the organisation's upper 
management among other types (optional and collective). They also conclude that construction professionals prefer to obtain innovation information from within their own interpersonal networks, in contrast to one of Rogers's generalisations that considers mass media the most important communication channel. Further, Gledson and Greenwood (2017: 958) correlate the company size with the personal use of 4D BIM and organisational BIM maturity with the personal use of 4D BIM.

Also basing their study on the DOI theory, Shibeika and Harty (2015: 456) describe the process through which a firm spreads digital innovation. The social system into which digital innovation is introduced is described as neither stable nor static; instead, the project-based nature of the company has a great effect on diffusion. Communication channels do not appear in the classic form of the DOl; alternatively, the digital spread is explained through a change in the firm's structural organisation and the key role of champions. Shibeika and Harty (2015: 461) define three phases of diffusion: (1) the centralisation of technology management wherein: a change in the organisational structure takes place, (2) standardisation of digital practices and (3) globalisation of project work.

Accordingly, Hosseini et al. (2016: 83) stress that industry and institutional factors affect organisational factors and that the latter manipulate project-level factors. Moreover, Hosseini et al. (2016: 75) merge these industry and institutional factors into one single embedded context named the supply chain, summarising the barriers involved in BIM adoption in three categories: (1) supply chain barriers, (2) organisational barriers and (3) project barriers.

Therefore, based on the findings and recent developments in DOI theory, this article groups the limitations of BIM adoption into three categories, as shown in Figure 1: (1) institutional barriers, (2) organisational/human barriers and (3) projectrelated/technological barriers.

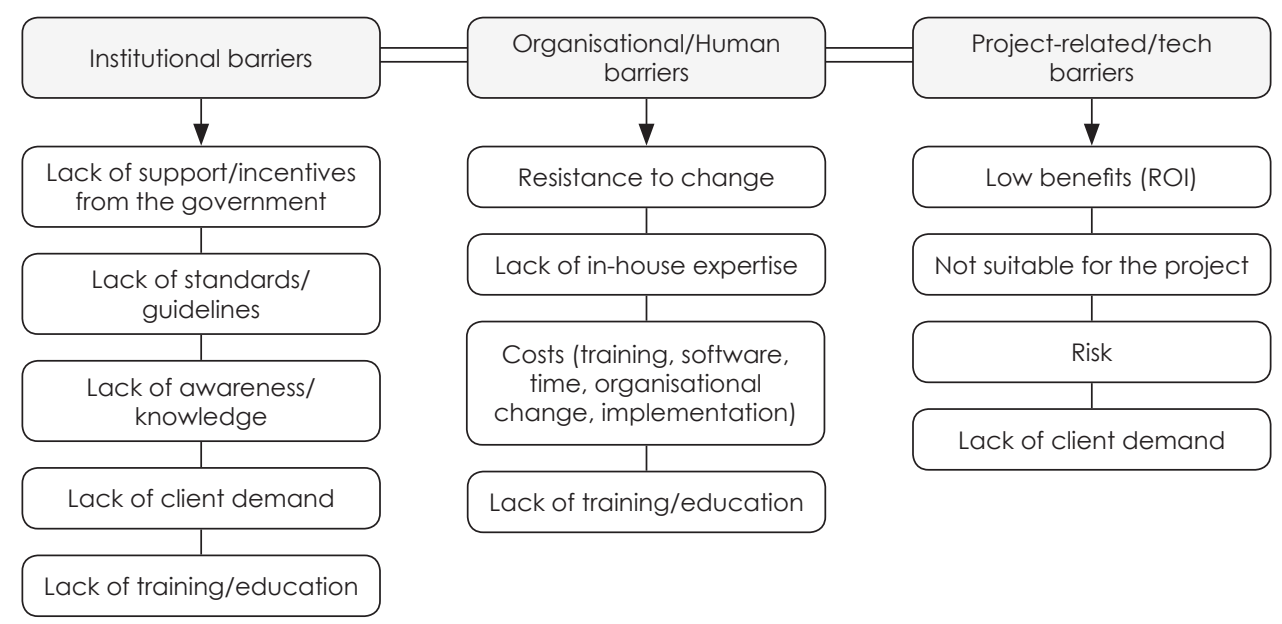

Figure 1. Three Main Categories of Challenges to BIM Adoption 


\section{RESEARCH METHODOLOGY}

While scrutinising various government strategies and experiences provides an insight into potential recommendations to tackle institutional barriers, this must be complemented with organisational solutions. Therefore, an online, web-hosted questionnaire survey was deployed to discuss the findings of the literature review and to address the hindrances to BIM adoption in terms of both institutional and organisational barriers. The questionnaire comprised three sections. The first clarified the aims of the research study and sought to acquire the demographic factors of the respondents. In relation to organisational barriers, the various traits and assumptions of DOI theory and its extensions were analysed and debated within the second section of the questionnaire, wherein the respondents who identified themselves as adopters were asked about their company's organisational structure, their level of BIM usage, the type of decisions made to adopt BIM and how they discovered BIM (the communication channels). This section of the questionnaire sought to compare and inspect the conditions necessary for BIM adoption (Shibeika and Harty, 2015: 463; Gledson and Greenwood, 2017: 957-963). Based on the literature review conducted, the third section listed 12 barriers (as shown in Figure 1) and asked the respondents to state their levels of agreement with these challenges. The survey used a 5-point Likert scale 11 = Strongly disagree, 2 = Disagree, 3 = Neutral, $4=$ Agree and $5=$ Strongly agree) since its aim was to gauge the perceptions of respondents concerning each barrier; the Likert scale was used because of the ordinal nature of the data (Croasmun, 2011: 20). The barriers were classified into three super-categories, as shown in Figure 1 (some barriers belonged to more than one category). The target population encompassed all of the construction-related companies across the Italian AEC industry. The utilised questions were premised on previous questionnaires conducted by NBS (2018), Hosseini et al. (2016: 78), Shibeika and Harty (2015: 463) and Gledson and Greenwood (2017: 957-963).

\section{RESULTS AND DISCUSSION}

\section{The Respondents' Profiles}

The online questionnaire survey was conducted and disseminated among companies, individuals and entities connected to the Italian AEC industry, that were working directly with BIM between 5th December 2018 and 5th February 2019. The bulk of respondents belonged to companies based in Lombardy, the province of Italy where the highest turnover rates had been recorded (Norsa, 2019: 4). A total of 78 complete responses were recorded. The first part of the questionnaire sought to gather demographic information about the respondents (as shown in Table 3). 
Behzad Karampour et al.

Table 3. The Respondents' Profiles

\begin{tabular}{|c|c|c|c|}
\hline Respondent Information & Category & $\%$ & Frequency \\
\hline \multirow[t]{2}{*}{ Gender } & Male & 79.5 & 62 \\
\hline & Female & 20.5 & 16 \\
\hline \multirow[t]{3}{*}{ Age } & 20 to 40 years old & 48.7 & 38 \\
\hline & 40 to 60 years old & 46.2 & 36 \\
\hline & $>60$ years old & 5.1 & 4 \\
\hline \multirow[t]{3}{*}{ Firm size (number of employees) } & Small (1 to 49) & 51.2 & 40 \\
\hline & Medium (50 to 249) & 25.7 & 20 \\
\hline & Large $(>250)$ & 23.1 & 18 \\
\hline \multirow[t]{3}{*}{ Experience in AEC industry } & 1 to 10 years & 48.8 & 38 \\
\hline & 11 to 20 years & 25.6 & 20 \\
\hline & $>20$ years & 25.6 & 20 \\
\hline \multirow[t]{6}{*}{ Company type } & Contractor & 5.1 & 4 \\
\hline & Manufacturer & 53.8 & 42 \\
\hline & Construction company & 7.7 & 6 \\
\hline & Architecture company & 15.4 & 12 \\
\hline & Engineering company & 10.3 & 8 \\
\hline & Consultant & 7.7 & 6 \\
\hline \multirow[t]{7}{*}{ Specialisation } & Director & 28.2 & 22 \\
\hline & Designer & 20.5 & 16 \\
\hline & Project manager & 23.1 & 18 \\
\hline & Engineer & 2.6 & 2 \\
\hline & Technician & 5.1 & 4 \\
\hline & Consultant & 17.9 & 14 \\
\hline & Owner & 2.6 & 2 \\
\hline \multirow[t]{3}{*}{ Job level } & Upper management & 35.9 & 28 \\
\hline & Middle management & 48.7 & 38 \\
\hline & Lower management & $15.40 \%$ & 12 \\
\hline \multirow[t]{4}{*}{ Primary clients of the company } & Government & $19.4 \%$ & 24 \\
\hline & Individuals/owners & $19.4 \%$ & 24 \\
\hline & Private organisations & $51.6 \%$ & 64 \\
\hline & Public organisations & $9.7 \%$ & 12 \\
\hline
\end{tabular}


Respondents acknowledged that $51.6 \%(n=64)$ of their primary clients were private organisations and individuals/owners and governments constituted $38.8 \%$ ( $n=48$ ) of the respondents' clients.

The respondents were asked whether they knew about or had used BIM. About $56 \%$ ( $n=44$ ) confirmed that they were BIM users and $36 \%$ were only aware of it $(n=28)$ and $8 \%(n=6)$ had neither used BIM nor were aware of it (as shown in Figure 2[a]). Further, of the $44 \%(n=34)$ that had never used BIM, 23\% ( $n=18)$ anticipated that they would be using it in a year's time, $10 \%(n=8)$ in 3 years' time; $8 \%(n=6)$ in 5 years' time and $3 \%(n=2)$ that they would never use it (as shown in Figure 2[b]).

(a)

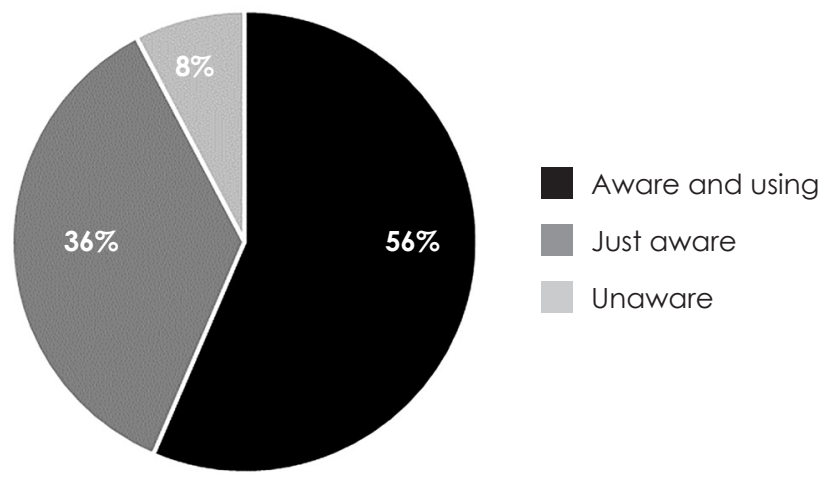

(b)

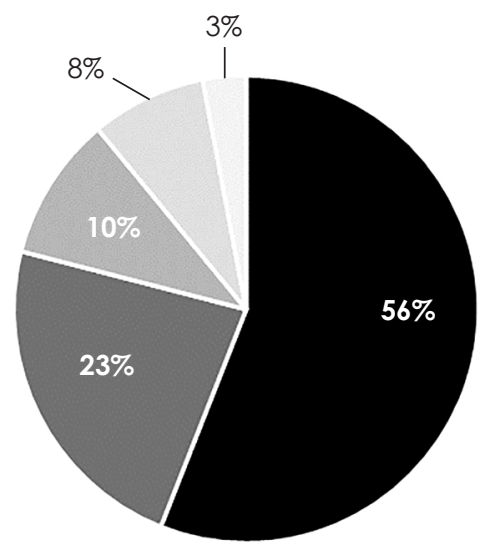

We currently use BIM

In one year time we will use BIM

In three year time we will use BIM

In five year time we will use BIM

We do not intend to use BIM

Figure 2. (a) BIM Usage and Awareness and (b) Future BIM Use

By applying the recommendations of the (NBS, 2018: 23) and descriptions of different BIM levels, the adopters' perceptions of their organisation's BIM maturity were appraised. As a result, $23 \%(n=10)$ identified their organisation's BIM maturity as Level $0,27 \%(n=12)$ as Level 1 and $50 \%(n=12)$ as Level 2 . The pie chart in Figure 3 displays these figures. 


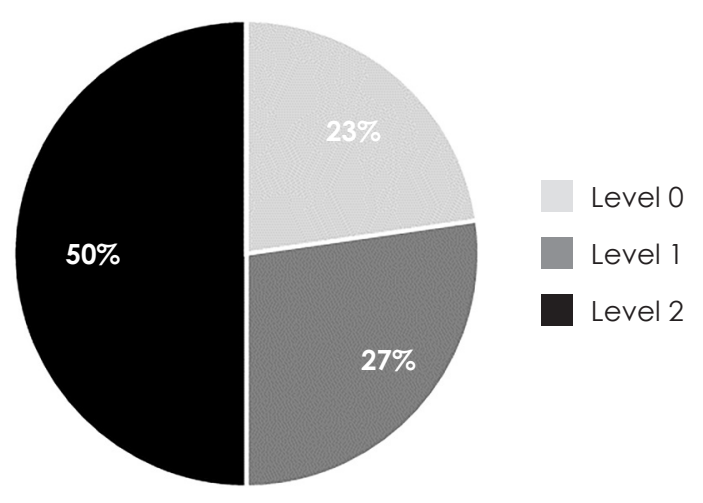

Figure 3. BIM Maturity

Those respondents who were identified as unaware of or who did not use BIM, were directed straight to the third and last section of the questionnaire and asked to reflect on the challenges of BIM adoption. The remaining respondents who had been identified as either adopters or aware of BIM, were asked to answer questions regarding their organisation's characteristics, types of decision and communication channels for BIM adoption; eventually, they were asked to elaborate with others on their thoughts about the barriers.

Pearson's correlation coefficient method, also referred to as Pearson's $r$ (Bryman and Cramer, 2005: 219), was employed to investigate the correlations between different variables because this method has proven to be the best means of measuring linear relationships (Jan and Tomasz, 201 1:92). The coefficient returns a value between -1 and +1 that represents the limits of correlation from a full negative correlation to a full positive correlation, where 0 means no correlation between the variables (Bryman and Cramer 2005: 219). Fisher's exact test, an inferential statistics analysis method, was also exploited to examine the significance of statistical relationships between variables (Jan and Tomasz, 2011: 88). In this method, $H_{0}$ (the null hypothesis) proves that the association between the variables has occurred by chance, whereas, conversely, $H_{1}$ (the alternative hypothesis) proves the existence of a correlation between the variables. This method was preferred to the Pearson's chi-square test since conditions for $X^{2}$ remained mostly unmet because numerous cells had been observed during comparisons and counts of less than 5 were expected.

\section{Rate of Adoption}

Reproducing Gledson and Greenwood's (2017: 958) assessment of the rate of adoption, it was done by comparing the first year of BIM awareness and the first year of BIM adoption. A majority of the respondents asserted that they became aware of BIM between 2012 and 2016 its earliest year of adoption was 2005 and its latest adoption was in 2018. The corresponding mean and median years for its adoption were 2013 and 2015, respectively. Most respondents adopted BIM between 2014 and 2018. Using Pearson's correlation coefficient method, a comparison was drawn between the first year of BIM awareness and the first year of its adoption. 
Using a linear regression, the linear correlation coefficient of 0.843 was obtained, which according to Bryman and Cramer (2005: 219) represents a strong positive relationship (as shown in Figure 4). The corresponding calculated variance was $R^{2}=0.71$. This suggests that the participants predominantly used BIM in the first year they were introduced to it.

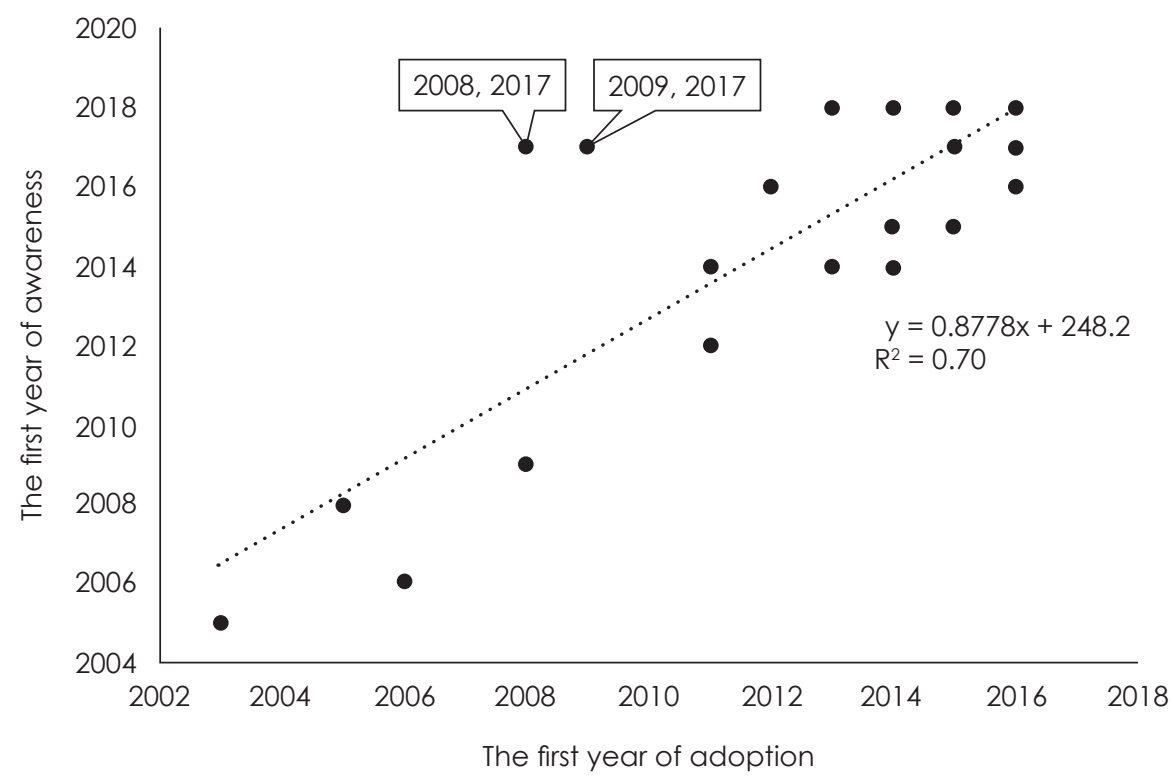

Figure 4. Correlation between the First Year of BIM Awareness and BIM Adoption

The outliers in Figure 4 were taken from the regression to Improve the results of the correlation. One respondent became aware of BIM in 2008 but opted to adopt it only in 2017. Another outlier reported the first year of awareness as 2009 but did not decide to adopt BIM until 2017. Interestingly, both of these 2 respondents chose to adopt BIM following a change in the organisation's structure. By excluding these outliers from the analysis, an average time lag of 1.9 years (around 23 months) between the time of awareness and adoption was calculated. This figure is slightly smaller than the results obtained by Gledson and Greenwood (2017: 958) that estimated the time lag to be around 2.38 to 3.00 years (28.5 to 36.0 months).

A comparison between the size of the company and the personal BIM use was conducted by formulating $H_{0}$ (the null hypothesis) and $H_{1}$ (the alternative hypothesis). These factors were defined as follows: (1) $H_{0}$, there is no relationship between company size and personal BIM use and (2) $H_{1}$, there is a relationship between company size and personal BIM use.

All 78 respondents were deemed eligible for Fisher's exact test (Bryman and Cramer, 2005: 219). The resulting p-value of 0.477 discounted $H_{1}$ in favour of $H_{0}$, contradicting Gledson and Greenwood's (2017: 958) assumptions that higher BIM use occurs within larger companies. It should also be noted that the definition of company size (number of employees) was adopted from the work of Gledson and Greenwood (2017: 958) in order to obtain a similar company size criterion. 
A comparison between organisational BIM maturity and personal BIM use was also made via the $H_{0}$ and $H_{1}$ criteria. The 72 respondents that identified themselves as adopters of BIM were used for a Fisher's exact test. The resulting p-value of $<0.0001$ discounted $H_{0}$ in favour of $H_{1}$. Therefore, as suggested by Gledson and Greenwood (2017: 957), higher personal BIM use occurs within companies that are considered to have higher BIM maturity.

\section{Organisational Structure}

As stated previously, the second section of the questionnaire focused on the organisational structure of the respondents. This allowed a comparison of the classical form of communication channels and decision types introduced by the DOI, with the organisational structures as described by Shibeika and Harty (2015: 464). In this regard, the subset of 44 respondents that identified themselves as adopters were asked whether they had experienced an organisational change within their companies leading to a centralisation of technology management that affected their decision to adopt BIM. About $82 \%$ ( $n=35$ ) of respondents confirmed that an organisational change had taken place that reflected their BIM adoption, whereas $18 \%(n=4)$ did not relate their decisions to an organisational change. Similarly, $82 \%(n=35)$ confirmed that their firms were operating outside Italy (globalisation) and $18 \%(n=4)$ stated that their organisations operated inside Italy only. Additionally, only $64 \%(n=28)$ believed that the standardisation of digital practices existed within their organisations, whereas $36 \%$ denied its existence. As shown in Figure 5, the organisational structure of the adopters' firms was consistent with the processes described by Shibeika and Harty (2015: 464) through which firms manage and spread digital innovations.
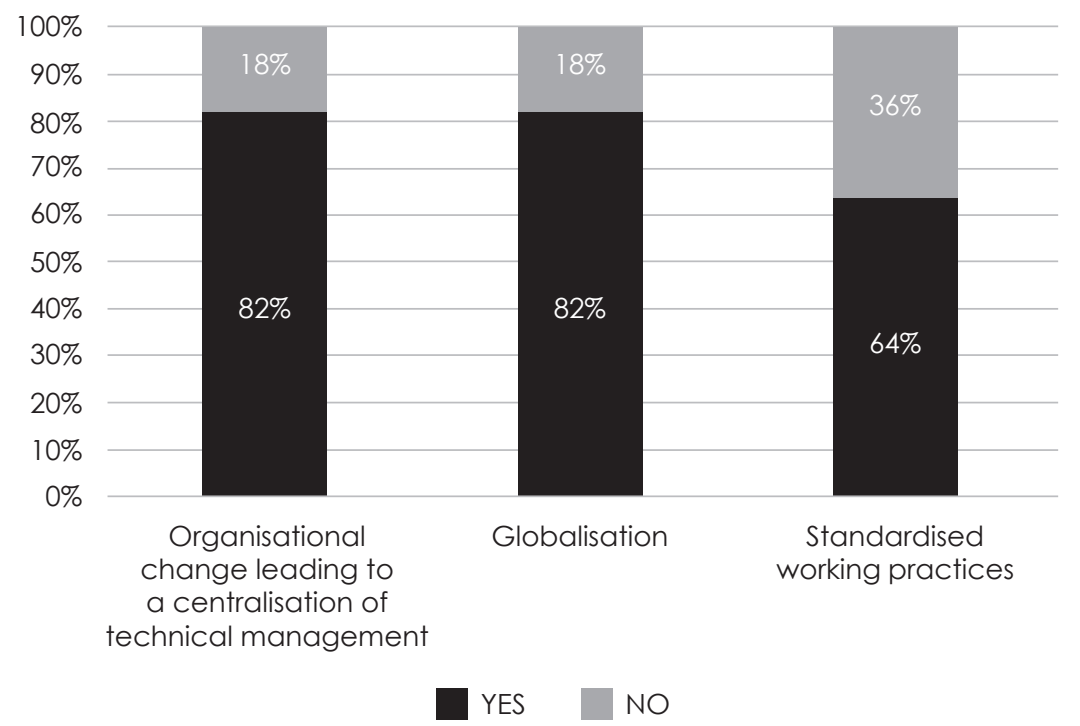

Figure 5. Firms' Organisational Structure 


\section{Decision Types}

The adopters were asked about the types of decision they used to adopt BIM according to the DOI. Where possible, response options comprised of: (1) individual decisions (optional), (2) decisions made consensually with others within the organisation (collective) and (3) decisions imposed by a single person or a handful of people in charge of the organisation (authority). The results are shown in Figure 6. The most frequent types of decision were the collective and the authority, each recording $36 \%(n=16)$, followed by the optional, which accounted for $28 \%$ $(n=12)$ of the adopters. These implications contradict the results reported by Gledson and Greenwood (2017:960), which indicate the superiority of the authoritytype decision. This could be because most of the respondents belong to small companies, meaning that the assumptions made by Gledson and Greenwood (2017: 960) hold true for big enterprises.

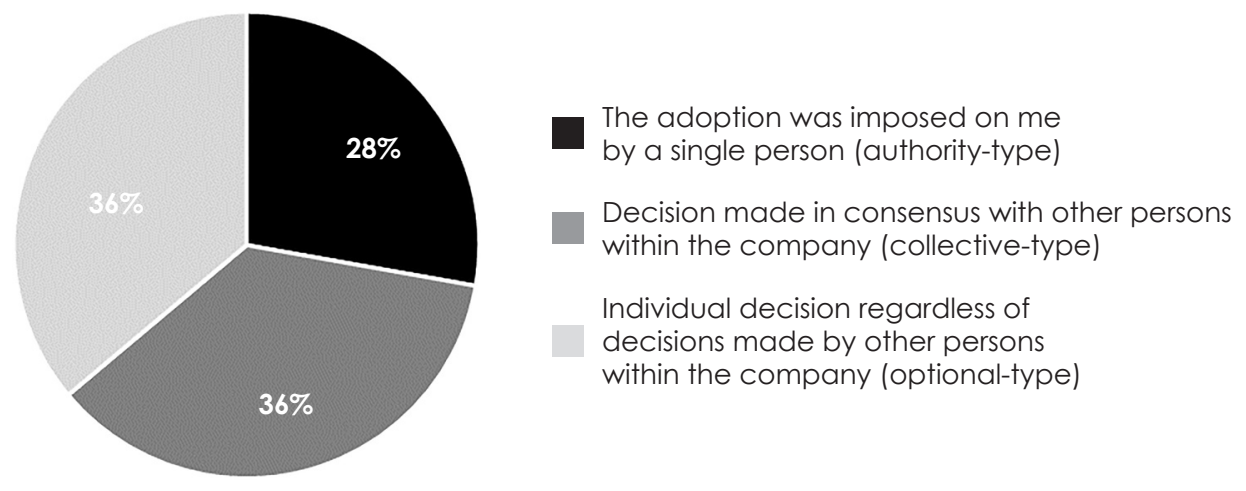

Figure 6. Decision Type

\section{Communication Channels}

The respondents identified as adopters or as being merely aware of BIM were asked about their communication channels with three possible response options: (1) external sources such as mass media, internet, journals, government and social media, (2) internal sources, such as interpersonal connections, colleagues and suppliers, and (3) champions who are experts in BIM and act as innovation promoters. Figure 7 provides bar charts depicting the results. For both adopters and respondents who were merely aware of the BIM, internal sources encompassed $50 \%$ of the communication channel. However, the most significant difference was found in the champions' proportion of the communication channels, nominated by $36 \%$ of adopters. Only $7 \%$ of those merely aware of BIM identified the champion as their communication channel. This is in line with predictions by Shibeika and Harty (2015: 464) and stresses the important role of champions. 


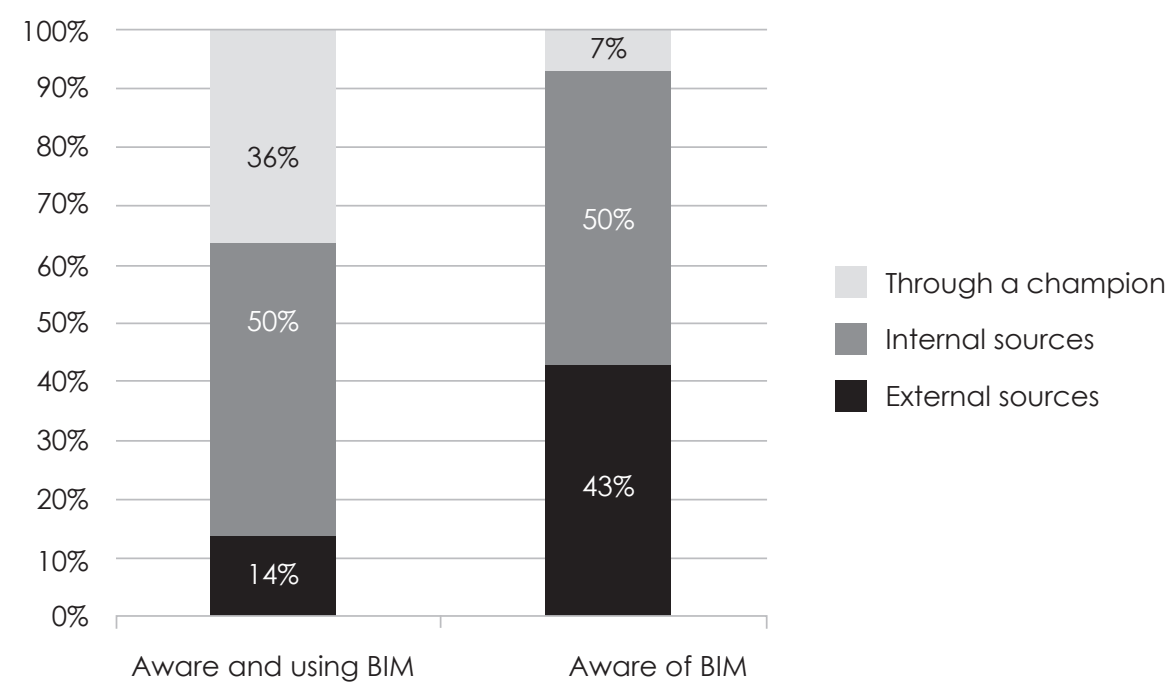

Figure 7. Communication Channels

\section{Challenges to BIM Adoption}

To further examine the significance of the aforementioned challenges to BIM adoption mentioned in the literature review, all 78 respondents were asked to state their level of agreement with the influence of each barrier on their decisions. This was conducted using a 5-point Likert scale $(1$ = Strongly agree, 2 = Agree, $3=$ Neutral, $4=$ Disagree and $5=$ Strongly disagree). After scrutinising the literature review and reflecting on the main barriers suggested in Hosseini et al. (2016: 78), 12 main statements were formulated using a 5-point Likert scale, as represented in Table 4. Each statement belongs to at least 1 of the 3 previously discussed barrier categories namely, institutional barriers, organisational and human barriers and project-related barriers.

Table 4. Questions Asked on the Survey

\begin{tabular}{|c|c|c|}
\hline Number & Question & Barrier Category \\
\hline S1 & $\begin{array}{l}\text { Our clients are not interested in using BIM in their } \\
\text { building projects }\end{array}$ & $\begin{array}{l}\text { Institutional/ } \\
\text { project-related }\end{array}$ \\
\hline S2 & $\begin{array}{l}\text { Our clients/sub-contractors do not have sufficient } \\
\text { knowledge about BIM and its benefits }\end{array}$ & Institutional \\
\hline S3 & $\begin{array}{l}\text { There is no official standard for adopting and using } \\
\text { BIM in building projects }\end{array}$ & Institutional \\
\hline S4 & There is no government support/initiative to use BIM & Institutional \\
\hline S5 & $\begin{array}{l}\text { The current technologies we are using are enough, } \\
\text { so we do not need BIM }\end{array}$ & Organisational \\
\hline
\end{tabular}


Table 4. Continued

\begin{tabular}{|c|c|c|}
\hline Number & Question & Barrier Category \\
\hline S6 & $\begin{array}{l}\text { Our firm is reluctant to adopt BIM because we do } \\
\text { not have sufficient knowledge about it }\end{array}$ & Organisational \\
\hline S7 & $\begin{array}{l}\text { Our firm does not have the skills and expertise for } \\
\text { BIM adoption }\end{array}$ & Organisational \\
\hline S8 & $\begin{array}{l}\text { There is a significant BIM implementation cost to our } \\
\text { firm }\end{array}$ & $\begin{array}{l}\text { Organisational/ } \\
\text { Project-related }\end{array}$ \\
\hline S9 & $\begin{array}{l}\text { There is insufficient training/education on how to } \\
\text { use BIM }\end{array}$ & $\begin{array}{l}\text { Institutional/ } \\
\text { Organisational }\end{array}$ \\
\hline S10 & $\begin{array}{l}\text { There is no or low benefit in adopting BIM in our } \\
\text { building projects }\end{array}$ & Project-related \\
\hline S11 & BIM is not suitable for our building projects & Project-related \\
\hline S12 & The risks linked to adopting BIM is too high & Project-related \\
\hline
\end{tabular}

For the purpose of evaluating the different barriers and their corresponding significance, a bar chart shown in Figure 8, was produced to reveal the distribution of responses for each question. To portray the variability and the central tendency of responses and to identify the most common responses in relation to each question, several statistical values were calculated. Since a Likert scale cannot define the distance between the data items, the mean value was of lesser importance. Instead, the inter-quartile range (IQR), the median and the mode values of the responses were analysed as the most important statistical values. The results are represented in Table 5. An additional bar chart was produced and half of the "Neutral" responses were construed as "Agreeing" and the other half as "Disagreeing" (as shown in Figure 9).

Table 5. Statistical Values of Responses

\begin{tabular}{lccc}
\hline Question & IQR & Median & Mode \\
\hline S1 & 1.75 & 3 & 4.0 \\
S2 & 1.75 & 2 & 1.0 \\
S3 & 2.00 & 2 & 2.0 \\
S4 & 2.00 & 2 & 2.0 \\
S5 & 1.00 & 4 & 4.0 \\
S6 & 1.00 & 4 & 4.0 \\
S7 & 2.00 & 4 & 4.0 \\
S8 & 1.00 & 2 & 2.0 \\
S9 & - & 2 & 2.0 \\
S10 & 2.00 & 4 & 4.0 \\
S1 & 2.00 & 4 & 4.0 \\
S12 & 2.00 & 4 & 4.0 \\
\hline
\end{tabular}




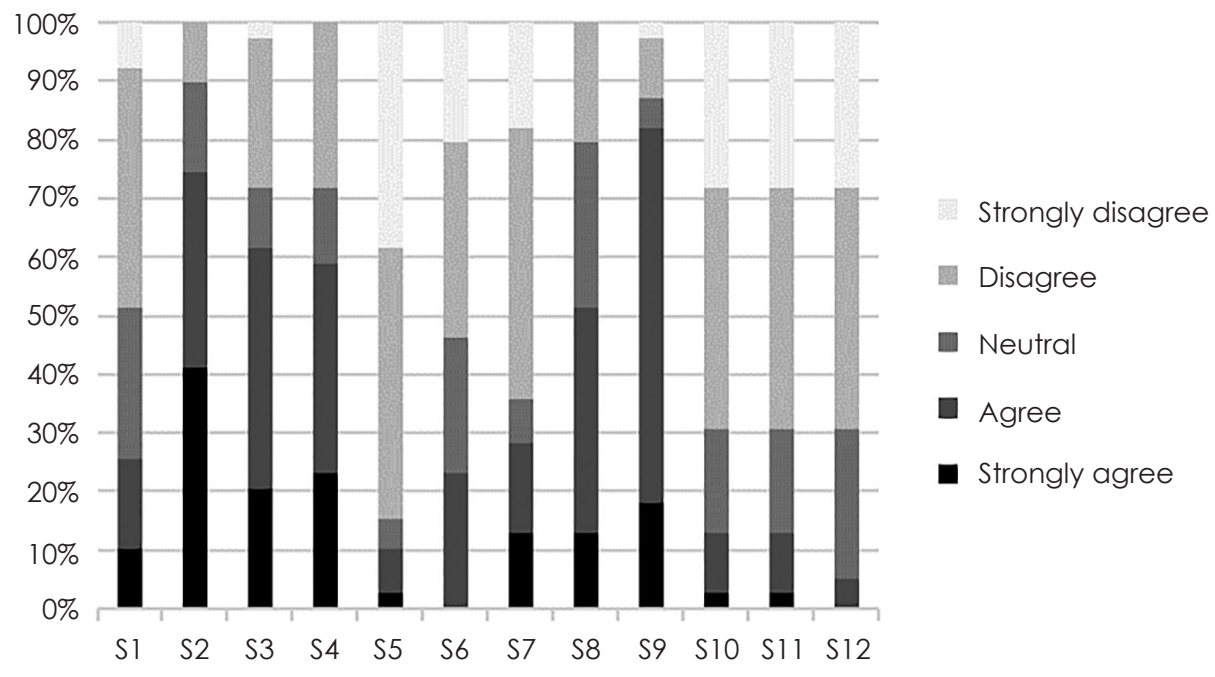

Figure 8. Distribution of Responses Related to Each Question

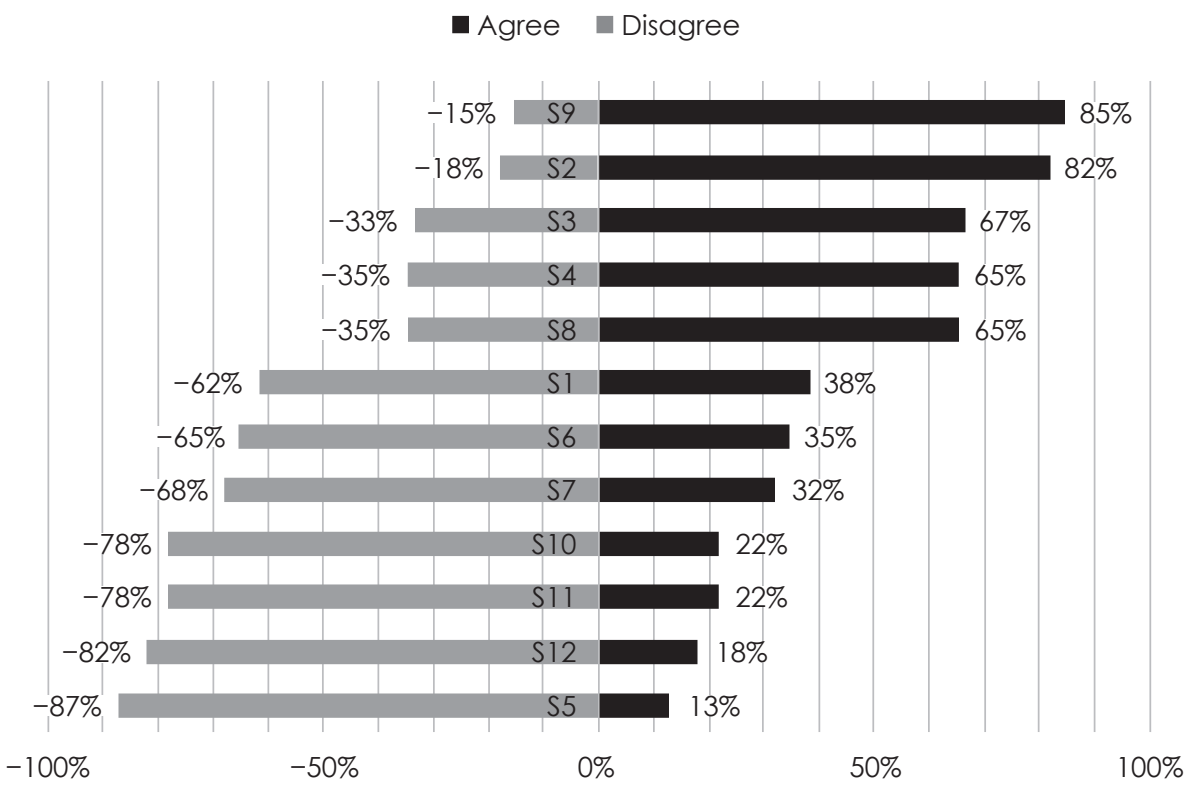

Figure 9. Level of Agreement in Relation to Each Question

Statements S9, S2, S8, S4 and S3 were selected as the most significant challenges to BIM adoption, all of which had a median value of 2 (implying "Agree"). Almost 85\% of respondents agreed that 59 posed a great challenge to BIM adoption; an IQR value of 0 a mode value of 2 implied that these responses 
were highly clustered around the most common response: 2 = Agree. Further, $82 \%$ of respondents recognised S2 as the second most significant barrier to BIM adoption. An IQR of 1.75 indicated that these responses were slightly more scattered than those of S9. S9 and S2 can therefore be assumed to be the most challenging barriers. Additionally, $65 \%$ identified 58 as the third most significant barrier to BIM adoption. S8 was deemed more challenging than S3, since it had a lower IQR value, suggesting that the responses were more clustered and less variable around the most common response: 2 = Agree. S4 and S3 were respectively the fourth and the 5th most significant barriers to BIM adoption.

\section{CONCLUSIONS AND RECOMMENDATIONS}

In view of the recent government BIM mandate, this study aimed at providing a strategic plan to accelerate BIM adoption in Italy by addressing the underlying challenges stemming from both organisational structures and institutional characteristics to avoid potential shortcomings to the current mandate. To this end, the study scrutinised and investigated the fundamentals of DOI within the private sector in Italy to reveal the most significant challenges to BIM implementation according to respondents and to provide appropriate solutions consistent with organisational structures. Subsequently, based on the results and by incorporating prevailing government strategies around the world, the study maps a set of recommendations that must be undertaken prior to the mandating of BIM in 2022. The study found that the most critical hindrances to BIM adoption emanate from (1) a lack of client knowledge about the BIM benefits embedded within the institutional context and (2) a lack of BIM training/education within the organisational context. The current $56 \%$ rate of adoption, in contrast to $74 \%$ in the UK (NBS, 2018: 19), signifies a comparatively sparse BIM-specialized industry. By reproducing the methods described by Gledson and Greenwood (2017: 958), the study found a correlation between the first year of awareness and the first year of adoption with an average time lag of 23 months between them, underlying the importance of further governmental actions to address one of the major obstacles to BIM adoption, according to respondents: the lack of BIM training or education. Contrary to Gledson and Greenwood's (2017: 958) assumptions, no association was detected between the company size and personal BIM use. It is noteworthy that higher levels of personal use occurred within companies with greater BIM maturity. In contrast to the DOI, the authority-type and the collective-type were both equally the most common decision types informing adoption. Given that the vast majority of respondents worked for small companies, it may be argued that the authoritytype is consistent only in larger companies. Likewise, the role of a champion, despite being disregarded in the DOI, was highlighted among the communication channels in which the DOl's internal sources still played a significant role. This latter is also strongly linked to one of the challenges to adoption in Italy, given that a champion can indirectly assist in training and educating workers.

Further, the organisational processes explained by Shibeika and Harty (2015: 464) for an innovation diffusion were deemed to be crucial where the centralisation of technical management in an organisation's structure and its affiliation with foreign companies and operating projects abroad played a key role. However, the existence of a standardised working practice proved dispensable. 
The findings of this study are subject to some limitations. The first limitation of the study concerns the sample size arising from a low response rate among Italian respondents. This reluctance to participate in the survey may have been caused by cultural factors. Nevertheless, the respondents were selected attentively from major private companies in the province of Lombardy in order to reflect the general opinion of the private sector and to avoid sample-bias. Moreover, at the first phase of the mandate's implementation, extending the findings to publicsector companies with distinct respondents in terms of organisational size and traits would assist us in assessing the rate of success of the government strategies for promoting BIM in the future.

\section{Recommendations to Tackle BIM Adoption Hurdles within the Italian AEC Industry}

In light of revelations about the predominant organisational challenges impeding BIM adoption in Italy, this study stresses the importance of increasing BIM knowledge and education among different stakeholders, which needs to be considered alongside the appropriate organisational structure. The government's success in addressing impediments, namely, clients' lack of knowledge about the benefits of BIM and reluctance to use it and the lack of BIM training and education, will depend on the speed with which it can bridge the gap between the industry and academia by implementing more BIM-incentivising policies. As discussed previously, governments can assume different roles to accelerate BIM implementation within the AEC industry.

Comparatively, the Italian industry has lacked a driving force in promoting BIM adoption from the very beginning. examples of such force may be found in: potent and persistent initial contributions by major public entities, which have led to nationwide diffusion in the US and Scandinavia; the establishment of a task force to connect industry and the academy by a government that affirms its role as a client, namely, the UK government; and a strong research and development presence and early BIM standard releases, as found in the Scandinavian countries.

Among the various countries discussed, Australia remains the only country to steer clear of BIM mandates. Its strategy is to foster BIM adoption through increasing stakeholder perceptions of BIM benefits via national BIM guidelines and initiatives, focusing on tackling software-related issues. Further, Australia established, albeit relatively late, a UK-lookalike BIM task force in 2016, which according to McGrawHill Construction (2015: 54), should help Australia to realise the higher level of contractor engagement compared to what has been seen among other countries.

This study found the reliance on the mandate alone to be inadequate and suggests replicating some of the Australian solutions the country that is deemed to be a "late bloomer" just like Italy.

Figure 10 shows the suggested areas for improvement for ltaly with respectively low levels of government contribution to BIM strategies. In view of the identified hurdles to BIM implementation in Italy and taking into account the characteristics of the industry in the country, it is evident that clients should be encouraged to adopt BIM and acknowledge its existing benefits, as well as receive training from experts. 


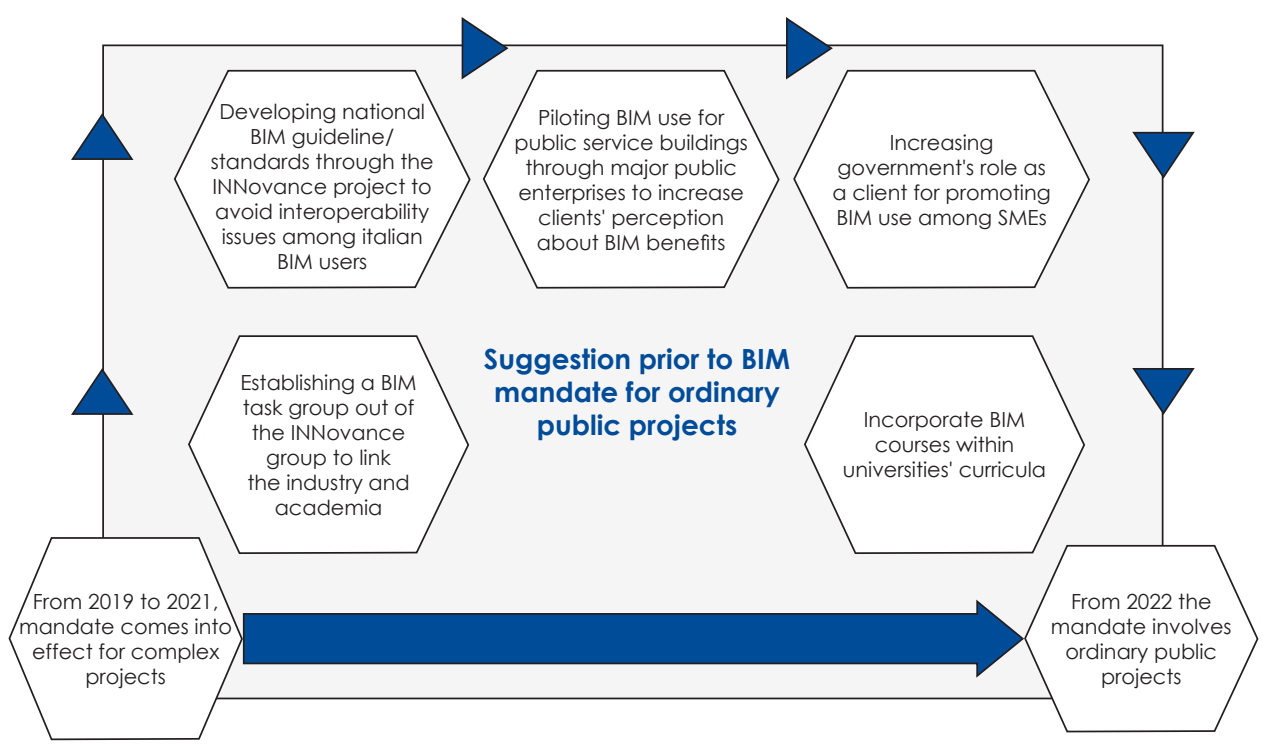

Figure 10. Suggested Prerequisites Prior to BIM Mandate for Ordinary Projects in 2022

The following scheme proposes a number of strategies that have proved crucial in other countries prior to mandating BIM use for ordinary public projects:

1. Developing national standards/guidelines through the INNovance project before 2022.

2. Piloting BIM use for public infrastructure projects to increase public perception of the benefits of BIM implementation. This may be conducted through major, non-profit public organisations that are involved in providing public building services.

3. Involving government. So far, the government has not played a role as a client but has acted as a sole enforcer of the strategy; therefore the government should assert itself as an interested client in BIM implementation.

4. Establishing a BIM task group in charge of reinforcing the connection between the industry and academia.

The responsibilities of this task group should include also incorporating BIM courses and programmes into university curricula (e.g., graduated students would satisfy the demand for specific roles connected with BIM within organisations). 


\section{REFERENCES}

Ahuja, R., Sawhney, A., Jain, M., Arif, M. and Rakshit, S. (2020). Factors influencing BIM adoption in emerging markets: The case of India. International Journal of Construction Management, 20(1): 65-76. https://doi.org/10.1080/15623599 .2018 .1462445 .

Ayinla, K.O. and Adamu, Z. (2018). Bridging the digital divide gap in BIM technology adoption. Engineering, Construction and Architectural Management, 25(10): 1398-1416. https://doi.org/10.1108/ECAM-05-2017-0091.

Bryman, A. and Cramer, D. (2005). Quantitative Data Analysis with SPSS 12 and 13: A Guide for Social Scientists With SPSS 12 and 13. London: Psychology Press.

Cao, D., Li, H., Wang, G. and Huang, T. (2017). Identifying and contextualising the motivations for BIM implementation in construction projects: An empirical study in China. International Journal of Project Management, 35(4): 658-669. https://doi.org/10.1016/j.jproman.2016.02.002.

Chan, C.T.W. (2014). Barriers of Implementing BIM in construction industry from the designers' perspective: A Hong Kong experience. Journal of System and Management Sciences, 4(2): 24-40.

Cheng, J.C.P. and LU, Q. (2015). A review of the efforts and roles of the public sector for BIM adoption worldwide enabling. Journal of Information Technology in Construction, 20(1): 442-478.

Croasmun, J.T. (2011). Using Likert-type scales in the social sciences. Journal of Adult Education, 40(1): 19-22.

European Construction Sector Observatory (2018). Country Profile Italy. Brussels, Belgium: European Commission.

Gledson, B. and Greenwood, D. (2017). The adoption of 4D BIM in the UK construction industry: An innovation diffusion approach. Engineering, Construction and Architectural Management, 24(6): 950-967. https://doi.org/10.1108/ECAM03-2016-0066.

Gu, N. and London, K. (2010). Understanding and facilitating BIM adoption in the AEC industry. Automation in Construction, 19(8): 988-999. https://doi.org/ 10.1016/j.autcon.2010.09.002.

HM Government (2013). Construction 2025: Strategy. London: Department for Business, Innovation and Skills.

Hosseini, M.R., Banihashemi, S., Chileshe, N., Namzadi, M.O., Udaeja, C., Rameezdeen, R. and McCuen, T. (2016). BIM adoption within Australian small and medium-sized enterprises (SMEs): An innovation diffusion model. Construction Economics and Building, 16(3): 71-86. https://doi.org/10.5130/ AJCEB.v16i3.5159.

Jan, H. and Tomasz, K. (2011). Comparison of values of Pearson's and Spearman's correlation coefficients. Quaestiones Geographicae, 30(2): 88-93. https://doi.org/10.2478/v10117-011-0021-1.

Jensen, P.A. and Jóhannesson, E.I. (2013). Building information modelling in Denmark and Iceland. Engineering, Construction and Architectural Management, 20(1): 99-110. https://doi.org/10.1108/09699981311288709.

Kassem, M., Brogden, T. and Dawood, N. (2012). BIM and 4D planning: A holistic study of the barriers and drivers to widespread adoption. Journal of Construction Engineering and Project Management, 2(4): 1-10. https://doi .org/10.6106/JCEPM.2012.2.4.001. 
Khosrowshahi, F. and Arayici, Y. (2012). Roadmap for implementation of BIM in the UK construction industry title roadmap for implementation of BIM in the UK construction industry. Engineering, Construction and Architectural Management, 19(6): 610-635. https://doi.org/10.1108/09699981211277531.

Matarneh, R. and Hamed, S. (2017). Barriers to the adoption of building information modeling in the Jordanian building industry. Open Journal of Civil Engineering, 7(3): 325-335. https://doi.org/10.4236/ojce.2017.73022.

McGraw-Hill Construction (2015). The Business Value of BIM for Construction in Major Global Markets. SmartMarket Report. Massachusetts: Mcgraw-Hill Construction.

(2012). The Business Value of BIM in North America: Multi-Year Trend Analysis and User Ratings. SmartMarket Report. Massachusetts: Mcgraw-Hill Construction.

Nanajkar, A. and Gao, Z. (2014). BIM implementation practices at India's AEC firms. In Y. Wang, H. Ye, G.Q.P. Shen and Y. Bai (eds.), ICCREM 2014: Smart Construction and Management in the Context of New Technology. Reston, VA: American Society of Civil Engineers, 134-139. https://doi.org/ 10.1061/9780784413777.016.

NBS (2018). National BIM Report 2018. Newcastle, UK: NBS. (2016). NBS International BIM Report 2016. Newcastle, UK: NBS.

Norsa, A. (2019). Rapporto Classifiche Le Prime 50 Imprese Italiane Dell'edilizia Privata. Milan: Società di Ricerca Guamari.

Park, K. and Kim, K. (2014). Essential BIM input data study for housing refurbishment: Homeowners' preferences in the UK. Buildings, 4(3): 467-487. https://doi.org/10.3390/buildings4030467.

Pasini, D., Caffi, V., Daniotti, B., Spagnolo, S.L. and Pavan, A. (2017). The INNOVance BIM library approach. Innovative Infrastructure Solutions, 2(1): 1-9. https://doi.org/10.1007/s41062-017-0062-y.

Rogers, E.M. (2003). Diffusion of Innovations. New York: Simon and Schuster Publications.

Rogers, J., Chong, H.-Y. and Preece, C. (2015). Adoption of building information modelling technology (BIM): Perspectives from Malaysian engineering consulting services firms. Engineering, Construction and Architectural Management, 22(4): 424-445. https://doi.org/10.1108/ECAM-05-2014-0067.

Roland Berger (2015). Digitization in the Construction Industry. Munich: Roland Berger $\mathrm{GmbH}$.

Shakil, A. and Hoque, M.I. (2018). Barriers to implementation of building information modeling (BIM) to the construction industry: A review. Journal of System and Management Sciences, 8(1): 45-60. https://doi.org/10.32732/ jcec.2018.7.2.107.

Sherif, M., Pyung, K.K., Tam, V.W.Y. and Payam, R. (2020). Exploring the status, benefits, barriers and opportunities of using BIM for advancing prefabrication practice. International Journal of Construction Management, 20(2): 146-156. https://doi.org/10.1080/15623599.2018.1484555.

Shibeika, A. and Harty, C. (2015). Diffusion of digital innovation in construction: A case study of a UK engineering firm. Construction Management and Economics, 33(5-6): 453-466. https://doi.org/10.1080/01446193.2015.1077982.

Sielker, F. and Allmendinger, P. (2018). International Experiences: Future Cities and BIM. Cambridge, UK: University of Cambridge. 
Smith, P. (2014). BIM implementation: Global strategies. Procedia Engineering, 85: 482-492. https://doi.org/10.1016/j.proeng.2014.10.575.

Wong, A., Wong, F.K.W. and Nadeem, A. (2010). Comparative roles of major stakeholders for the implementation of BIM in various countries. In H. Wamelink, M. Prins and R. Geraedts (eds.), Changing Roles: New Roles, New Challenges. Delft, Netherlands: Delft University of Technology, 23-33.

Ya'acob, I.A.M., Rahim, F.A.M. and Zainon, N. (2018). Risk in Implementing building information modelling (BIM) in Malaysia construction industry: A review. E3S Web of Conferences, 65: 1-9. https://doi.org/10.1051/e3sconf/ 20186503002.

Zahrizan, Z., Ali, N.M., Haron, A.T., Marshall-Ponting, A. and Hamid, Z.A. (2013). Exploring the adoption of building information modelling (BIM) in the Malaysian construction industry: A qualitative approach. International Journal of Research in Engineering and Technology, 2(8): 384-395. https://doi.org/10.15623/ijret.2013.0208060. 